Review

\title{
Worldwide distribution of HLA-B27 and Behcet Disease: a systematic review and meta-analysis
}

\author{
Alireza Khabbazi, Azizeh Farshbaf-Khalili, Leila Vahedi \\ Tabriz University of Medical Sciences, Tabriz, Iran \\ Received 19 May 2018, Revised 06 April 2019, Accepted 26 June 2019
}

(C) 2018, Khabbazi A., Farshbaf-Khalili A., Vahedi L.

(C) 2018, Russian Open Medical Journal

\begin{abstract}
Objective - Performing global population-based studies and comparing the results with other studies can reveal regional differences in the distribution of HLA-B27 in patients with Behcet disease. The aim of study was reviewing the distribution of HLA-B27 and Behcet disease in the world.

Material and Methods - A systematic review search was conducted of the MeSH keywords of Behcet disease, HLA-B27 and B27 in ProQuest, Scopus, EMBASE, SID, IranDoc and IranMedex from 1975 to 2017 in Iran. Data was analyzed using meta-analysis (random effect model) in Software CMA2. The heterogeneity of studies was assessed with I ${ }^{2}$ index

Results - The pooled frequency of HLA-B27 in patients with patients throughout the world for 11,483 samples and 36 studies was $7.4 \%$. A higher frequency of HLA-B27 was found in Europe for, followed by the Middle East (7.2 (4.5-11.7)\%, P<0.001) and Far East (6.4 (2.1-19.4)\%, $P<0.001)$. By country, the highest frequency was found for Great Britain $16.7 \%$ (8.6-33.1), followed by Iran $7.2 \%$ (4.5-11.7) and Turkey 5.9 (3.6-9.9)\%.

Conclusion - The results demonstrate the role of HLA-B genes such as -B27 on Behcet disease and provide information about the causes and effects of the subject to help design health programs and carry out future investigations on the odds ratio.
\end{abstract}

Keywords: Behçet disease, HLA-B27, Distribution

Cite as Khabbazi A, Farshbaf-Khalili A, Vahedi L. Worldwide distribution of HLA-B27 and Behcet Disease: a systematic review and meta-analysis. Russian Open Medical Journal 2019; 8: e0303.

Correspondence to Leila Vahedi. E-mail: vahedi.149@gmail.com. Phone: +9141042900. Fax: +4133373741.

\section{Introduction}

Behcet disease (BD) is a vascular autoimmune disease [1] which is characterized by recurrent oral ulcers, genital ulcers, skin lesions and ocular involvement [2]. BD has been frequently reported in the Mediterranean basin and Far East between $30^{\circ}$ and $45^{\circ} \mathrm{N}$ latitude and was spread along the ancient Silk Road by migrating Turks [3, 4]. Today, BD has been observed in Europe, America and Oceania [3, 4]. The etiology of this disease is unknown, but genetic and environmental factors play an important role in its emergence $[3,4]$. Human leukocyte antigen (HLA) class I alleles, especially HLA-B51, is strongly associated with $\mathrm{BD}[4,5]$; however, it expresses a marker for other genes in linkage disequilibrium (LD) with it $[3,4,6]$. The major histocompatibility complex (MHC), a group of genes that code proteins found on the surfaces of cells, is essential for the acquired immune system that is known in humans as the HLA [3, $4,6]$. Recent investigations have compared HLA-B27 in different populations and ethnicities with various clinical manifestations of $B D$ $[5,7]$. Although the diagnosis of $B D$ is based on clinical presentation, HLA markers may be significant in the diagnosis and prognosis of the disease [8].

Understanding the prevalence, distribution and population influence of HLA-B27 is important for health care planning. Demographic and population studies have focused on size, distribution, migration, composition and socioeconomic factors. The results of these studies have been applied to government decisionmaking and analysis of the causes and outcomes of population change [9].

Although there have been studies on HLA-B51 in BD around the world, none have systematically compared the pooled frequency of HLA-B27 in different geographical regions.

To address this gap, the present research undertook a systematic review of published studies to evaluate the frequency of HLA-B27 in BD patients as primary aim and Behcet Disease as secondary aim among continents and countries for the design of health programs and in preparation of future research.

\section{Material and methods}

\section{Inclusion and exclusion criteria}

This study was a systematic review and meta-analysis of all cross-sectional studies which evaluated the frequency distribution of HLA-B27 in BD between January 1975 and February 2017 according to Preferred Reporting Items for Systematic Reviews and MetaAnalyses (PRISMA) checklist and PICO approach [10] (participants: patients with $\mathrm{BD}$; interventions: genetic background for HLA-B27; comparison and outcome: None) [11]. Moreover, due to the 
rareness of $\mathrm{BD}$ in some areas, a number of articles were also included that did not conform to the PRISMA checklist to allow coverage of specific items in the results.

The inclusion criteria consisted of all subtypes of HLA-B27 with or without concomitance with other types of HLA and all ages, sexes, countries and ethnicities as well as without language limitation. The exclusion criteria were studies reporting on animal studies, case reports, case series, letters, clinical trials and disagreements between reviewers, as well as studies in which a subset of BD patients (uveitis and arthritis) were excluded.

\section{Search strategy}

PubMed, ProQuest, Scopus, EMBASE, SID (Scientific Information Database), IranDoc (Iranian Research Institute for Information Science and Technology), Magiran and IranMedex were searched by combining MeSH keywords of Behcet disease, Behcet's syndrome, HLA-B27, B27, Frequency and their combinations. References of the related reviewed studies were surveyed manually. Unpublished studies and "gray" literatures (such as studies presented at congresses or working papers) were searched. In the case of unpublished studies or ambiguous data, we contacted the authors for more information.

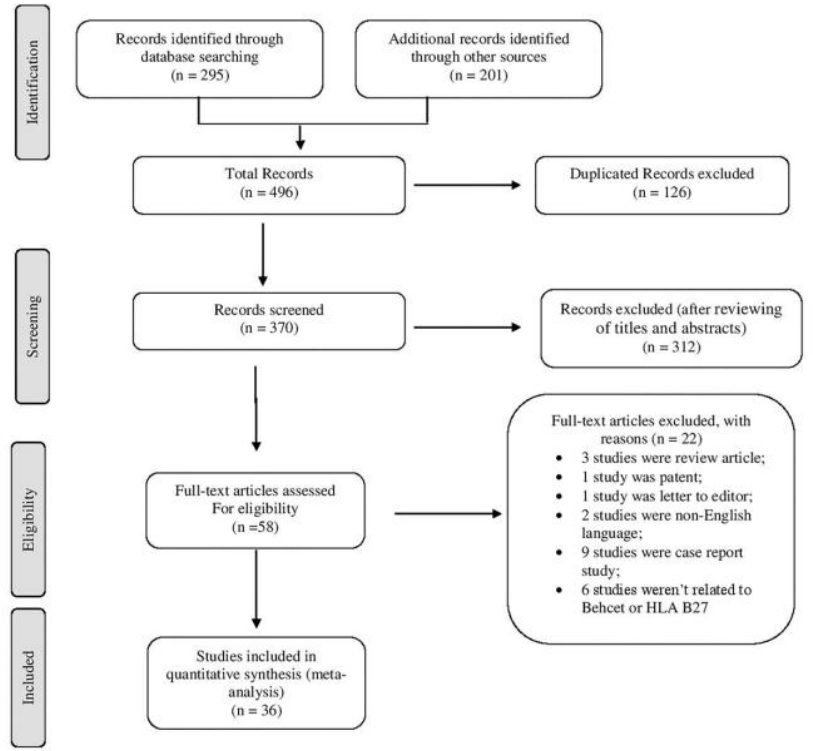

Figure 1. Flow diagram of trials for inclusion in the systematic review and meta-analysis.

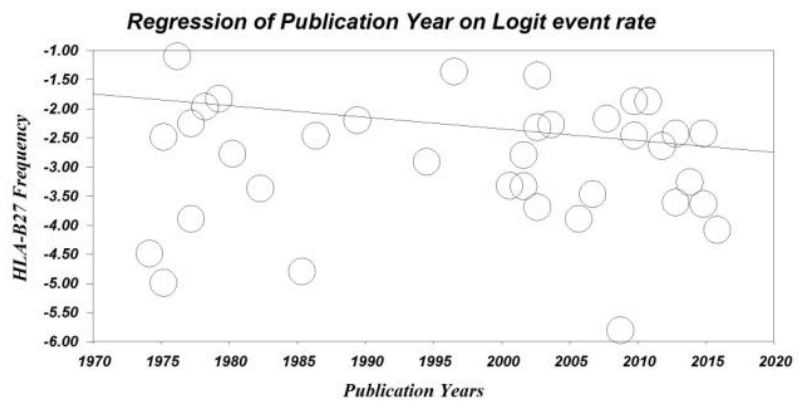

Figure 2. Meta-Regression based on the date of publication.

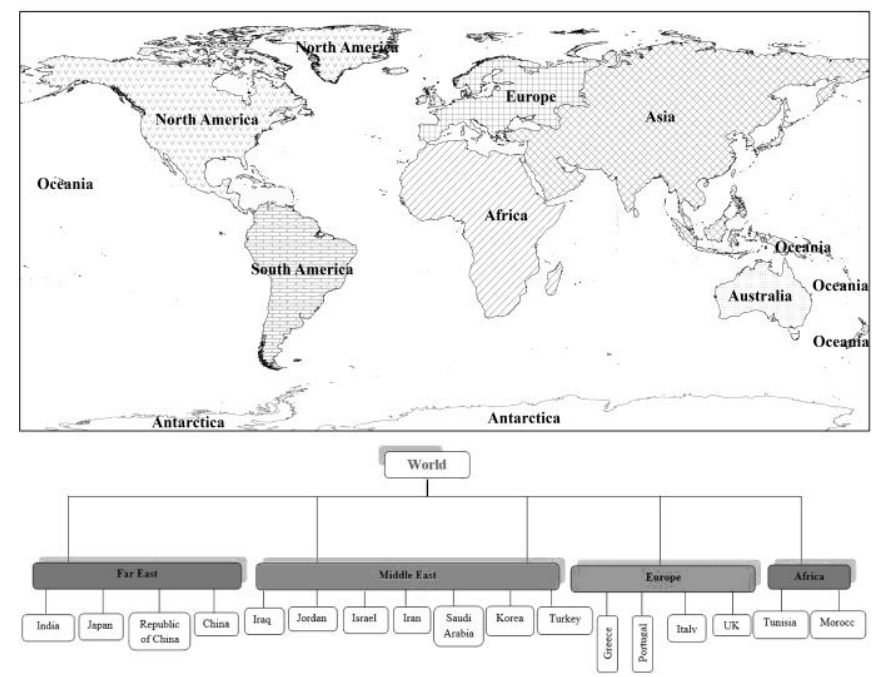

Figure 3. A neighbor-joining tree (dendrogram) and Geographical map for Behcet's disease based on countries and continent.

\section{Selection process}

Each paper was independently controlled by two reviewers (K.A and V.L). Any disagreements between the two reviewers were solved by the third reviewer (G.M). The article is excluded if it did not get credit score from the third reviewer. The Kappa agreement rate was higher than $85 \%$.

\section{Data extraction and data analysis}

The variables which were extracted from the articles were the name of the first author, publication date and location of the study, sample size and frequency of the HLA-B27 antigen summarized in extracted form. The continents were divided to five groups, including Far East, Middle East, Europe, Africa and America. The Turkey was categorized in the Middle East.

The systematic review was surveyed at by least two appraisers. The frequency, percentage and ratio were used as definite variables. Endnote X5 was used to organize the data, review the titles and abstracts and identify duplicated studies. A funnel plot was used to check for the existence of publication bias. It should be mentioned, at the beginning of the meta-analysis, logarithmic transformation was carried out for the frequency of HLA-B27, due to close to zero this value in a number of articles. Thus, the forest plot has been reported based on negative numbers following this logarithmic transformation.

The meta-analysis was performed using a random effect model for $I^{2}>50$ or $p<0.05$. The pooled event rate was calculated to determine the frequency of HLA-B27 in BD-patients. Heterogeneity between studies was calculated by Cochran's $Q$ and $I^{2}$ tests to examine the percentage of changes between studies using the software CMA v.2.0 (Biostat Inc, USA) [12]. The results of the meta-analysis are presented as forest plots. Results were considered significant at $P<0.05$.

\section{Ethical subject}

This study has been conducted at the Connective Tissue Disease Research Center (CTDR) in Tabriz University of Medical Sciences (Tabriz, Iran). All data were kept stating the name of patients and addresses. 
Table 1. Frequency of HLA-B27 in Behcet disease based on Logit event rate, lower limit to upper limit

\begin{tabular}{|c|c|c|c|c|c|}
\hline Continent & Authors & Event Rate (log) & Lower limit to Upper limit & Z value & P-value \\
\hline \multirow{7}{*}{ Far East } & Pande I (1995) & -2.90 & $(-4.07)$ to $(-1.74)$ & -4.90 & $<0.001$ \\
\hline & Takano M. et al (1976) & -4.99 & $(-7.77)$ to $(-2.20)$ & -3.50 & $<0.001$ \\
\hline & Ohno S. et al (1975) & -4.48 & $(-7.27)$ to $(-1.70)$ & -3.10 & 0.002 \\
\hline & Chung Y-M. et al (1987) & -246 & $(-3.48)$ to $(-1.44)$ & -4.70 & $<0.001$ \\
\hline & Cibo H. et al (1997) & -1.35 & $(-2.09)$ to $(-0.62)$ & -3.60 & $<0.001$ \\
\hline & Subtotal & -2.73 & $(-3.83)$ to $(-1.63)$ & -4.80 & $<0.001$ \\
\hline & Rawi Z. et al (1986) & -4.79 & $(-7.57)$ to $(-2.01)$ & -3.30 & 0.001 \\
\hline \multirow{16}{*}{ Middle East } & Mustafa TAA (2003) & -1.42 & $(-1.87)$ to $(-0.98)$ & -6.20 & $<0.001$ \\
\hline & Brautbar C. et al (1978) & -3.89 & $(-6.69)$ to $(-1.09)$ & -2.70 & 0.006 \\
\hline & Xavier JM. et al (2015) & -3.63 & $(-4.03)$ to $(-3.23)$ & -17.90 & $<0.001$ \\
\hline & Fatemi A.et al (2015) & -2.42 & $(-2.72)$ to $(-2.12)$ & -15.90 & $<0.001$ \\
\hline & Chams-Davatchi C. et al (2003) & -2.32 & $(-3.24)$ to $(-1.40)$ & -4.90 & $<0.001$ \\
\hline & Amirzargar A.et al (2010) & -1.87 & $(-2.73)$ to $(-1.01)$ & -4.20 & $<0.001$ \\
\hline & Davatchi F. et al (2010) & -2.46 & $(-2.55)$ to $(-2.37)$ & -53.40 & $<0.001$ \\
\hline & Al-Okaily F. et al (2016) & -4.07 & $(-6.05)$ to $(-2.10)$ & -4.04 & $<0.001$ \\
\hline & Chang HK. et al (2002) & -2.79 & $(-3.95)$ to $(-1.62)$ & -4.60 & $<0.001$ \\
\hline & Moon S-J. et al (2013) & -2.42 & $(-3.60)$ to $(-1.24)$ & -4.03 & $<0.001$ \\
\hline & Yazici H. et al (1980) & -1.82 & $(-2.76)$ to $(-0.88)$ & -3.70 & $<0.001$ \\
\hline & Muftuocl AU. et al (1981) & -2.77 & $(-3.53)$ to $(-2.00)$ & -7.10 & $<0.001$ \\
\hline & Gul A. et al (2002) & -3.33 & $(-4.14)$ to $(-2.51)$ & -8.02 & $<0.001$ \\
\hline & Pirim I. et al (2004) & -2.27 & $(-3.05)$ to $(-1.49)$ & -5.70 & $<0.001$ \\
\hline & Mizuki N. et al (2007) & -3.46 & $(-5.45)$ to $(-1.47)$ & -3.40 & 0.001 \\
\hline & Ombrelloa MJ (2014) & -3.26 & $(-3.56)$ to $(-2.95)$ & -21.20 & $<0.001$ \\
\hline \multirow{12}{*}{ Europe } & Subtotal & -2.65 & $(-2.98)$ to $(-2.32)$ & -15.75 & $<0.001$ \\
\hline & Zouboulis CC. et al (2003) & -3.68 & $(-5.09)$ to $(-2.28)$ & -5.10 & $<0.001$ \\
\hline & Munoz-Saa I. et al (2006) & -3.89 & $(-6.69)$ to $(-1.09)$ & -2.70 & 0.006 \\
\hline & Montes-Cano MA.et al (2013) & -3.61 & $(-4.31)$ to $(-2.90)$ & -10 & $<0.001$ \\
\hline & Bettencourt A. et al (2008) & -2.16 & $(-2.90)$ to $(-1.43)$ & -5.80 & $<0.001$ \\
\hline & Piga M.et al (2012) & -2.63 & $(-3.81)$ to $(-1.46)$ & -4.40 & $<0.001$ \\
\hline & Olivieri I. et al (1990) & -2.19 & $(-3.65)$ to $(-0.73)$ & -2.90 & 0.0030 \\
\hline & Chamberlain MA (1978) & -2.25 & $(-3.70)$ to $(-0.79)$ & -3.02 & 0.0020 \\
\hline & Lehner T. et al (1979) & -1.96 & $(-2.70)$ to $(-1.22)$ & -5.20 & $<0.001$ \\
\hline & Caporn BN. et al (1983) & -3.36 & $(-6.18)$ to $(-0.54)$ & -2.30 & 0.010 \\
\hline & Chamberlain MA (1977) & -1.09 & $(-1.95)$ to $(-0.24)$ & -2.51 & 0.010 \\
\hline & Subtotal & -2.51 & $(-3.10)$ to $(-1.80)$ & -7.93 & $<0.001$ \\
\hline \multirow{4}{*}{ Africa } & Sakily N. et al (2009) & -5.80 & $(-8.57)$ to $(-3.02)$ & -4 & $<0.001$ \\
\hline & Radouane A. et al (2011) & -1.87 & $(-2.39)$ to $(-1.34)$ & -6.90 & $<0.001$ \\
\hline & Choukri F. et al (2001) & -3.32 & $(-4.47)$ to $(-2.16)$ & -5.60 & $<0.001$ \\
\hline & Subtotal & -3.20 & $(-4.91)$ to $(-1.50)$ & -3.60 & $<0.001$ \\
\hline America & O'Duffy JD .et al (1976) & -2.48 & $(-3.92)$ to $(-1.04)$ & -3.30 & 0.001 \\
\hline
\end{tabular}

\section{Results}

In the systematic review, 496 articles were identified. Of these, 126 were excluded as duplicates, 312 studies were excluded after initial title and abstract reviews and 22 were excluded after full text review. A final total of 36 articles fulfilled the inclusion criteria as shown in the flow chart of search articles in Figure 1.

Data from BD patients in the Far East, Middle East, Europe, Africa and America were pooled separately. The analysis showed the overall heterogeneity among continents and countries where $1^{2}>60 \%$ expectation of UK is shown in Table 1 . The pooled overall frequency of HLA-B27 in BD patients globally was 7.4\% [(Cl 95\% 5.8-9.4), $\mathrm{P}<0.001$ ] for a total of 11,483 samples (Table 2 ).

The results showed the pooled frequency of HLA-B27 was more common in European than in the Middle East, Far East and Africa, which suggests a difference among regions. Comparison among countries indicates that the UK had higher combined HLAB27 than Iran and Turkey (Table 1). The higher pooled frequency of HLA-B27 was related to Chamberlain MA in UK [13]. Moreover, Middle East populations had a higher BD patient rate than others and results showed similar samples among subgroups.

Up to the year 2000, the overall frequency of BD patients, HLAB27 and articles were calculated $683(6 \%), 49(6 \%)$ and $15(30 \%)$, while these items, after the year 2000 were calculated 10800 (94\%), $723(94 \%)$ and $36(70 \%)$, respectively. Indeed, it indicates increasing the number of $\mathrm{BD}$ patients and improving the detection of the pathogenic mutations in deoxyribonucleic acid (DNA). Comparison between continents showed further reports has been published in the Far East before 2000 year and in Africa after this year.

A meta-regression was performed based on the date of publication. Meta-regression results showed that the HLA-B27 frequency decreases by $2 \%$ per year $(P<0.001)$ (Figure 2 ).

Furthermore, ArcGIS Version-9.3 mapping software as a georeferenced digital map was used for analyzing and depicting geographic and mapped information in a database. A neighborjoining tree (dendrogram) has been drawn for country and continents (Figure 3 ).

\section{Discussion}

BD is a common autoimmune disease globally [14] with multifactorial pathogenesis such as genetic factors play a critical role. There is a strong correlation between BD and human MHC [3]. This systematic review and meta-analysis was carried out to investigate the distribution of HLA-B27 in BD and Behcet Diseases in subgroups as defined by continents and countries. To the best our knowledge, this is the first study was conducted on the distribution of B27 and Behcet's Disease.

The current study has shown that the HLA-B27 frequency was $7.4 \%$ in $B D$ patients and the number of individuals affected by $B D$ was 11,483 cases. 
Table 2. Characteristics of articles related toHLA-B27 in Behcet disease across the world

\begin{tabular}{|c|c|c|c|c|c|c|c|c|}
\hline \multirow{2}{*}{ Continents } & \multirow{2}{*}{ Authors } & \multirow{2}{*}{ Places } & \multicolumn{2}{|c|}{$\begin{array}{c}\text { Cases } \\
N=36 \text { Papers }\end{array}$} & \multirow{2}{*}{$\begin{array}{c}\text { Pooled rate } \\
\text { Effect size and } 95 \% \\
\text { confidence interval }\end{array}$} & \multicolumn{3}{|c|}{ Heterogeneity } \\
\hline & & & $\begin{array}{l}\text { Sample Size } \\
\mathrm{F}(\%) \text { (Case) }\end{array}$ & $\begin{array}{l}\text { HLA-B27 } \\
\text { F (Case) }\end{array}$ & & $\mathrm{df}(\mathrm{Q})$ & P-value & $1^{2}$ \\
\hline \multirow{6}{*}{ Far East } & Pande I (1995) [28] & India & $58(0.5)$ & 3 & - & - & - & - \\
\hline & Takano M. et al (1976) [29] & Japan & $73(0.6)$ & 0 & - & - & - & - \\
\hline & Ohno S. et al (1975) [30] & Japan & $44(0.4)$ & 0 & - & - & - & - \\
\hline & Chung Y-M. et al (1987) [31] & China & $51(0.4)$ & 4 & - & - & - & - \\
\hline & Cibo H. et al (1997) [32] & China & $44(0.4)$ & 9 & - & - & - & - \\
\hline & Subtotal & & $270(2.4)$ & 16 & $\begin{array}{c}6.4(2.1-19.4) \%, \\
P<0.001\end{array}$ & 4 & 0.010 & 69.69 \\
\hline \multirow{18}{*}{$\begin{array}{l}\text { Middle } \\
\text { East }\end{array}$} & Rawi z. et al (1986) [33] & Iraq & $60(0.5)$ & 0 & 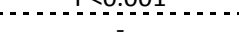 & - & - & - \\
\hline & Mustafa TAA (2003) [34] & Jordan & $124(1.1)$ & 24 & - & - & - & - \\
\hline & Brautbar C. et al (1978) [35] & Israel & $24(0.2)$ & 0 & - & - & - & - \\
\hline & Xavier JM. et al (2015) [36] & Iran & $973(8.5)$ & 25 & & & & \\
\hline & Fatemi A.et al (2015) [37] & Iran & $577(5.0)$ & 47 & & & & \\
\hline & Chams-Davatchi C. et al (2003) [14] & Iran & $56(0.5)$ & 5 & 7.2\% (4.5-11.7), & 4 & $<0.001$ & 88.42 \\
\hline & Amirzargar A.et al (2010) [38] & Iran & $45(0.4)$ & 6 & & & & \\
\hline & Davatchi F. et al (2010) [39] & Iran & $6500(56.6)$ & 511 & & & & \\
\hline & Al-Okaily F. et al (2016) [40] & $\begin{array}{l}\text { Saudi } \\
\text { Arabia }\end{array}$ & $60(0.5)$ & 1 & - & - & - & - \\
\hline & Chang HK. et al (2002) [41] & Korea & $52(0.5)$ & 3 & - & - & - & - \\
\hline & Moon S-J. et al (2013) [42] & Korea & $37(0.3)$ & 3 & - & - & - & - \\
\hline & Yazici H. et al (1980) [43] & Turkey & $36(0.3)$ & 5 & & & & \\
\hline & Muftuocl AU. et al (1981) [44] & Turkey & $119(1)$ & 7 & & & & \\
\hline & Gul A. et al (2002) [19] & Turkey & $174(1.5)$ & 6 & $5.9(3.6-9.9) \%$, & & & \\
\hline & Pirim I. et al (2004) [15] & Turkey & $75(0.7)$ & 7 & $P<0.001$ & 5 & 0.021 & 62.34 \\
\hline & Mizuki N. et al (2007) [18] & Turkey & $33(0.3)$ & 1 & & & & \\
\hline & Ombrelloa MJ (2014) [45] & Turkey & $1190(10.4)$ & 44 & & & & \\
\hline & Subtotal & & $10135(88.3)$ & 695 & $\begin{array}{c}7.0(5.0-9.8) \%, \\
P<0.001\end{array}$ & 16 & $<0.001$ & 83.09 \\
\hline \multirow{11}{*}{ Europe } & Žouboulis CC. et al (2003) [46] & Greece & $82(0.7)$ & 2 & - & - & - & - \\
\hline & Munoz-Saa I. et al (2006) [47] & Spain & $24(0.2)$ & 0 & - & - & - & - \\
\hline & Montes-Cano MA.et al (2013) [48] & Spain & $304(2.6)$ & 8 & - & - & - & - \\
\hline & Bettencourt A. et al (2008) [49] & Portugal & $78(0.7)$ & 8 & - & - & - & - \\
\hline & Piga M.et al (2012) [50] & Italy & $45(0.4)$ & 3 & - & - & - & - \\
\hline & Olivieri I. et al (1990) [51] & Italy & $20(0.2)$ & 2 & - & - & - & - \\
\hline & Chamberlain MA (1978) [52] & UK & $28(0.2)$ & 7 & & & & \\
\hline & Lehner T. et al (1979) [53] & UK & $65(0.6)$ & 8 & $16.7(8.6-33.1) \%$, & 3 & חم2 ח & 2963 \\
\hline & Caporn BN. et al (1983) [54] & UK & $14(0.1)$ & 0 & $\mathrm{P}<0.001$ & 3 & 0.200 & 29.63 \\
\hline & Chamberlain MA (1977) [13] & UK & $21(0.2)$ & 2 & & & & \\
\hline & Subtotal & & $681(5.9)$ & 40 & $\begin{array}{c}8.0(4.3-15.0) \%, \\
P<0.001\end{array}$ & 9 & 0.001 & 66.69 \\
\hline \multirow{4}{*}{ Africa } & Saḱly N. et al (2009) [7] & Tunisia- & $165(1.4)$ & 0 & 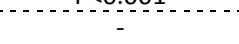 & $\because$ & - & - \\
\hline & Radouane A. et al (2011) [55] & Morocco & $120(1.0)$ & 16 & - & - & - & - \\
\hline & Choukri F. et al (2001) [56] & Morocco & $86(0.7)$ & 3 & - & - & - & - \\
\hline & Subtotal & & $371(3.2)$ & 19 & $\begin{array}{c}4.0(0.7-22.1) \%, \\
\mathrm{P}<0.001\end{array}$ & 2 & 0.003 & 82.73 \\
\hline \multirow{2}{*}{$\begin{array}{l}\text { America } \\
\text { Total }\end{array}$} & O'Duffy JD. et al (1976) [57] & & $26(0.2)$ & $\because$ & 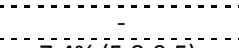 & - & -1 & - \\
\hline & & & $11483(100)$ & 772 & $\begin{array}{c}7.4 \%(5.8-9.5), \\
P<0.001\end{array}$ & 35.00 & $<0.001$ & 76.67 \\
\hline
\end{tabular}

The pooled frequency of HLA-B27 in BD patients was greater in Europe, followed by the Middle East, Far East and Africa. Among countries, the UK ranked first, followed by Iran and Turkey. The highest number of samples has been recorded in the Middle East, especially Iran, and the proportion in other continents and countries was similar or lower. Previous meta-analyses have reported on the strong correlation between HLA-B51 and BD, but the current analysis suggests the necessity of investigation of B27 in $\mathrm{BD}[6,15,16]$. Likewise, Gül believed that, despite the strong association of HLA-B51 with $\mathrm{BD}$, there is controversy about this association due to a role of the MHC class I variants [17].

It is not known whether HLA-B51 is a BD susceptibility gene itself or if this strong association displays linkage disequilibrium with another gene or other HLA-B genes $[16,17]$.

$\mathrm{BD}$ is known as the Silk Road disease because it spread along that ancient and historical route from the Far East (Japan, Korea,
China) to the Mediterranean basin (Turkey, Tunisia, Morocco) [3, 4]. On the other hand, -B51 frequency was observed first in Arabs, Turks and Jews and in the Far East [6]. According to reported papers, the geographical distribution of genes, such as HLA-B51 or others at near it, is potentially related to the global distribution of $B D[18,19]$. This distribution is more solid in B51, because of it's strongly association. In this study, the distribution of HLA-B51 differs slightly with BD. Nonetheless, the pool of BD in peoples carrying a high frequency of HLA-B51 could relate to the fact that genetic susceptibility to BD is secondary either to HLA-B51 subtypes or to genes near LD with HLA-B51 [6].

Today, HLA-B27 is a subject of study in medicine as related to the pathogenesis of diseases such as BD. This antigen has several subtypes with variety frequencies, distributions and clinical manifestations in different populations and ethnicities due to impression other MHC and non-MHC genes [20]. This systematic 
review highlights the role of B27 and other factors. A higher pooled frequency of HLA-B27 was found from the data in Europe than in other places.

The spread of HLA-B27 and BD in Europe, especially in the UK was an interesting finding of this study. The UK has invested in molecular diagnostic techniques and the management of information. The improvement in molecular diagnosis and recording information from sources such as hospitals, laboratories and medical clinics could justify this alternation.

Of notes, a review study reported that BD is prevalent in the Middle East, followed by the Far East, North Africa, Europe, the USA and Australia because it was spread by human migration along the Silk Road from the Far East to the West [6]. The Silk Road contributed strongly to the spread between the East and West because of the economic, political, religious, and cultural exchange that elevated immigration from East to West [21]. Therefore, this finding relates to the number of Asian migrants to these places. The proximity of Europe to the Mediterranean region and increased migration between these areas has increased the gene flow and the spread a number of diseases. It is likely that genetic diversity and some types of disease in Europe and even America are associated with these events [22]. It is suggested that this disease was spread by Turks from northern China to Iran, Turkey, Europe, Africa and America [23].

A founder effect can occur during migration. This can result in genetic isolation and inter-ethnic marriage that allows the frequency of the allele for BD to persist and increase over time [24]. America has been exposed to these changes at much lower rate.

It is possible that the emergence of $\mathrm{BD}$ has declined due to random events such as genetic drift [25], Bottleneck effect [26] environmental factors [27] and failure to report. Moreover, it is likely that BD cases with other backgrounds have been seen in these regions and it is necessary to carry out further investigation.

The difference in the frequency of disease and related genes should be investigated in demographic studies among immigrants. Takeuchi et al. determined that the frequency of BD among Turkish immigrants dropped to less than the Turkish people, but was more than in Germans [16].

\section{Strength and Limitation}

The advantage of the current study is the use of pooled data for analysis and, for the first time, different geographical regions were compared for HLA-B27 subject to BD.

This study was limited by incomplete information that prevented subgroup analysis for sex and age. Ultimately, this study surveyed the incidence of BD with a HLA-B27 background. Analysis ofHLA-B27 frequency independent ofHLA-B51, in a subset of BD or in control and cases groups is recommended.

\section{Conclusion}

The results show the pathogenic role of other HLA-B genes, such as B27, on BD in addition to HLA-B51. A higher frequency of HLA-B27 in Europeans in Asia and Africa has been documented. To determine a possible higher frequency of patients in the Middle East than in Europe and Africa and using more publications from the Far East to up to the year 2000, several hypotheses could be considered, including the effect of migration, other genetic factors, environmental factors, improvement in the detection of pathogenic mutations in DNA and increased reporting. Moreover, identification of the geographical distribution and how different causes can effect healthcare system planning and government decisions such as implementation of $\mathrm{BD}$ care programs or the design of molecular diagnostic kits should be considered. Other studies comparing the frequency HLA-B27 between BD patients and controls and the determination of pooled frequency of HLAB27 independent ofHLA-B51are needed.

Conflict of interest: none declared.

\section{Acknowledgment}

We would like to thank all authors that have been used their results of studies in this study and Leila Khabbazi for editing our manuscript.

\section{References}

1. Direskeneli H. Autoimmunity vs autoinflammation in Behcet's disease: do we oversimplify a complex disorder? Rheumatology (Oxford) 2006; 45(12): 1461-1465. https://doi.org/10.1093/rheumatology/kel329.

2. Chams-Davatchi $C$, Shizarpour M, Davatchi F, Shahram F, Chams H, Nadji A, et al. Comparison of oral aphthae in Behcet's Disease and idiopathic recurrent aphthous stomatitis. Adv Exp Med Biol 2003; 528: 317-320. https://doi.org/10.1007/0-306-48382-3 62.

3. Cohen R, Metzger S, Nahir M, Chajek-Shaul T. Association of the MIC-A gene and HLA-B51 with Behcet's disease in Arabs and non-Ashkenazi Jews in Israel. Ann Rheum Dis 2002; 61(2): 157-160. https://doi.org/10.1136/ard.61.2.157.

4. Gül A. Behçet's disease: an update on the pathogenesis. Clin Exp Rheumatol 2001; 19(5, Suppl 24): S6-S12. https://www.ncbi.nlm.nih.gov/pubmed/11760403.

5. Pineton de Chambrun M1, Wechsler B, Geri G, Cacoub P, Saadoun D. New insights into the pathogenesis of Behcet's disease. Autoimmun
Rev
2012;
$11(10)$
687-698. https://doi.org/10.1016/j.autrev.2011.11.026.

6. Piga M, Mathieu A. Genetic susceptibility to Behcet's disease: role of genes belonging to the MHC region. Rheumatology (Oxford) 2010 50(2): 299-310. https://doi.org/10.1093/rheumatology/keq331.

7. Sakly N, Boumiza R, Zrour-Hassen S, Hamzaoui A, Ben Yahia S, Amara $\mathrm{H}$, et al. HLA-B27 and HLA-B51 Determination in Tunisian Healthy Subjects and Patients with Suspected Ankylosing Spondylitis and Behçet's Disease. Ann N Y Acad Sci 2009; 1173: 564-569. https://doi.org/10.1111/j.1749-6632.2009.04756.x.

8. Ahmad T, Wallace GR, James T, Neville M, Bunce M, Mulcahy-Hawes K et al. Mapping the HLA association in Behcet's disease: a role for tumor necrosis factor polymorphisms? Arthritis Rheum 2003; 48(3): 807-813. https://doi.org/10.1002/art.10815

9. Tiwari R, Singh R, Zodpey S. Landscaping academic programs offered in demography and population studies in India. Indian J Public Health 2015; 59(3): 178-188. https://doi.org/10.4103/0019-557X.164655.

10. Rafeey M, Ghojazadeh M, Sheikhi S, Vahedi L. Caustic ingestion in children: a systematic review and meta-analysis. J Caring Sci 2016; 5(3): 251-265. https://doi.org/10.15171/ics.2016.027.

11. Shamseer L, Moher D, Clarke M, Ghersi D, Liberati A, Petticrew M, et al. Preferred reporting items for systematic review and meta-analysis protocols (PRISMA-P) 2015: elaboration and explanation. BMJ 2015; 349: g7647. https://doi.org/10.1136/bmj.g7647.

12. Higgins JPT, Green S. Cochrane handbook for systematic reviews of interventions. The Cochrane Collaboration, 2011.

13. Chamberlain MA. Behcet's syndrome in 32 patients in Yorkshire. Ann Rheum Dis 1977; 36(6): 491-499. https://doi.org/10.1136/ard.36.6.491.

14. Chams-Davatchi C, Shizarpour M, Davatchi F, Shahram F, Chams H, Nadji A, et al. Comparison of oral aphthae in Behçet's Disease and 
idiopathic recurrent aphthous stomatitis. Adv Exp Med Biol 2003; 528 : 317-320. https://doi.org/10.1007/0-306-48382-3 62.

15. Pirim I, Atasoy M, Ikbal M, Erdem T, Aliagaoglu C. HLA class I and class II genotyping in patients with Behcet's disease: a regional study of eastern part of Turkey. Tissue Antigens 2004; 64(3): 293-297. https://doi.org/10.1111/j.1399-0039.2004.00280.x.

16. Takeuchi M, Kastner DL, Remmers EF. The immunogenetics of Behcet's disease: A comprehensive review. J Autoimmun 2015; 64: 137-148. https://doi.org/10.1016/j.jaut.2015.08.013.

17. Gül A, Hajeer AH, Worthington J, Barrett JH, Ollier WE, Silman AJ. Evidence for linkage of the HLA-B locus in Behçet's disease, obtained using the transmission disequilibrium test. Arthritis Rheum 2001; 44(1): 239-241. $\quad$ https://doi.org/10.1002/15290131(200101)44:1<239::AID-ANR31>3.0.CO;2-X.

18. Mizuki N, Meguro A, Tohnai I, Gül A, Ohno S, Mizuki N. Association of major histocompatibility complex class I chain-related gene A and HLAB alleles with Behçet's disease in Turkey. Jpn J Ophthalmol 2007; 51(6): 431-436. https://doi.org/10.1007/s10384-007-0473-y.

19. Gül A, Uyar FA, Inanç $M$, Ocal L, Barrett JH, Aral O, et al. A weak association of HLA-B* 2702 with Behçet's disease. Genes Immun 2002; 3(6): 368-372. https://doi.org/10.1038/sj.gene.6363863.

20. Sheehan NJ. HLA-B27: what's new? Rheumatology (Oxford) 2010; 49(4): 621-631. https://doi.org/10.1093/rheumatology/kep450

21. Leonardo NM, McNeil J. Behçet's disease: is there geographical variation? A review far from the Silk Road. Int J Rheumatol 2015; 2015: 945262. https://doi.org/10.1155/2015/945262.

22. Yao YG, Kong QP, Wang CY, Zhu CL, Zhang YP. Different matrilineal contributions to genetic structure of ethnic groups in the silk road region in china. Mol Biol Evol 2004; 21(12): 2265-2280. https://doi.org/10.1093/molbev/msh238.

23. James DG. Silk route disease'(Behçet's disease). West J Med 1988; 148(4): 433-437. https://www.ncbi.nlm.nih.gov/pubmed/3291395.

24. Jaber L, Milo G, Halpern GJ, Krause I, Weinberger A. Prevalence of Behcet's disease in an Arab community in Israel. Ann Rheum Dis 2002; 61(4): 365-366. https://doi.org/10.1136/ard.61.4.365.

25. Rabinovich $E$, Shinar $Y$, Leiba $M$, Ehrenfeld $M$, Langevitz $P$, Livneh $A$. Common FMF alleles may predispose to development of Behcet's disease with increased risk for venous thrombosis. Scand J Rheumatol 2007; 36(1): 48-52. https://doi.org/10.1080/03009740600759639.

26. Zidan J, Ben-Avraham D, Carmi S, Maray T, Friedman E, Atzmon G. Genotyping of geographically diverse Druze trios reveals substructure and a recent bottleneck. Eur J Hum Genet 2015; 23(8): 1093-1099. https://doi.org/10.1038/ejhg.2014.218.

27. Rizvi SW, McGrath $\mathrm{H}$ Jr. The therapeutic effect of cigarette smoking on oral/genital aphthosis and other manifestations of Behçet's disease. Clin Exp Rheumatol 2001; 19(5, Suppl 24): S77-78. https://www.ncbi.nlm.nih.gov/pubmed/11760408.

28. Pande I, Uppal SS, Kailash S, Kumar A, Malaviya AN. Behçet's disease in India: a clinical, immunological, immunogenetic and outcome study. $\mathrm{Br}$ J Rheumatol 1995; 34(9): 825-830. https://www.ncbi.nlm.nih.gov/pubmed/7582721.

29. Takano M, Miyajima T, Kiuchi M, Ohmori K, Amemiya H. Behcet disease and the HLA system. Tissue Antigens 1976; 8(2): 95-99. https://www.ncbi.nlm.nih.gov/pubmed/968901.

30. Ono S, Nakayama E, Sugiura S, Itakura K, Aoki K. Specific histocompatibility antigens associated with Behçet's disease. Am J Ophthalmol 1975; 80(4): 636-641. https://doi.org/10.1016/00029394(75)90394-3.

31. Chung YM, Tsai ST, Liao F, Liu JH. A genetic study of Behcet's disease in Taiwan Chinese. Tissue Antigens 1987; 30(2): 68-72. https://www.ncbi.nlm.nih.gov/pubmed/3672493.

32. Cibo H, Yi L, Ming CXX, Yuzhen D, Qingong $M$. Determination of HLA antigen in Behcet's disease. CNKI J 1997; R597.9.
33. Al-Rawi ZS, Sharquie KE, Khalifa SJ, Al-Hadithi FM, Munir JJ. Behçet's disease in Iraqi patients. Ann Rheum Dis 1986; 45(12): 987-990. https://doi.org/10.1136/ard.45.12.987.

34. Mustafa TAA, Hadid AA. Clinical Pattern of Behcet Disease in Jordan. Qatar Med J. 2003; 12(2): 124-128. https://www.researchgate.net/publication/316846850_Clinical_Patter n_of_Behcet_Disease_in_Jordan.

35. Brautbar C, Chajek T, Ben-Tuvia S, Lamm L, Cohen T. A Genetic Study of Behqet Disease in Israel. Tissue Antigens 1978; 11(2): 113-120. https://www.ncbi.nlm.nih.gov/pubmed/644568.

36. Xavier JM, Shahram F, Davatchi F, Rosa A, Crespo J, Abdollahi BS, et al. Association study of IL10 and IL23R-IL12RB2 in Iranian patients with Behcet's disease. Arthritis Rheum 2012; 64(8): 2761-2772. https://doi.org/10.1002/art.34437.

37. Fatemi A, Shahram F, Akhlaghi M, Smiley A, Nadji A, Davatchi F. Prospective study of articular manifestations in Behcet's disease: fiveyear report. Int J Rheum Dis 2017; 20(1): 97-102. https://doi.org/10.1111/1756-185X.12633.

38. Amirzargar A, Shahram F, Nikoopour E, Rezaei N, Saeedfar K, Ziaei N, et al. Proinflammatory cytokine gene polymorphisms in Behcet's disease. Eur Cytokine Netw 2010; 21(4): 292-296. https://doi.org/10.1684/ecn.2009.0209.

39. Davatchi F, Shahram F, Chams-Davatchi C, Shams H, Nadji A, Akhlaghi $\mathrm{M}$, et al. Behcet's disease in Iran: analysis of 6500 cases. Int J Rheum Dis 2010; 13(4): 367-373. https://doi.org/10.1111/j.1756185X.2010.01549.x.

40. Al-Okaily F, Al-Rashidi S, Al-Balawi M, Mustafa M, Arfin M, Al-Asmari A Genetic Association of HLA-A*26, -A*31, and -B*51 with Behcet's Disease in Saudi Patients. Clin Med Insights Arthritis Musculoskelet Disord 2016; 9: 167-173. https://doi.org/10.4137/CMAMD.S39879.

41. Chang HK, Lee DH, Jung SM, Choi SJ, Kim JU, Choi YJ, et al. The Comparison Between Behcet's Disease and Spondyloarthritides: Does Behcet's Disease Belong to the Spondyloarthropathy Complex? J Korean Med Sci 2002; 17(4): 524-529. https://doi.org/10.3346/jkms.2002.17.4.524.

42. Moon SJ, Oh EJ, Kim Y, Kim KS, Kwok SK, Ju JH, et al. Diversity of killer cell immunoglobulin-like receptor genes in uveitis associated with autoimmune diseases: ankylosing spondylitis and Behçet disease. Ocul Immunol Inflamm 2013; 21(2): 135-143. https://doi.org/10.3109/09273948.2012.754905.

43. Yazici H, Chamberlain MA, Schreuder I, D'amaro J, Muftuoglu M. HLA antigens in Behçet9s disease: a reappraisal by a comparative study of Turkish and British patients. Ann Rheum Dis 1980; 39(4): 344-348. https://doi.org/10.1136/ard.39.4.344.

44. Müftuüğlu A, Yazici $H$, Yurdakul S, Pazarli $H$, Özyazgan $Y$, Tüzün $Y$, et al. Behçs Disease: Lack of Correlation of Clinical Manifestations with HLA Antigens. Tissue Antigens 1981; 17(2): 226-230. https://www.ncbi.nlm.nih.gov/pubmed/7233417.

45. Ombrello MJ, Kirino Y, de Bakker PI, Gül A, Kastner DL, Remmers EF. Behçet disease-associated $\mathrm{MHC}$ class I residues implicate antigen binding and regulation of cell-mediated cytotoxicity. Proc Natl Acad SCi $\begin{array}{lllll} & S & A & 2014 ; & 111(24):\end{array}$ https://doi.org/10.1073/pnas.1406575111.

46. Zouboulis CC, Vaiopoulos G, Marcomichelakis N, Palimeris G, Markidou I, Thouas B, et al. Onset signs, clinical course, prognosis, treatment and outcome of adult patients with Adamantiades-Behçet's disease in Greece. Clin Exp Rheumatol 2003; 21(4 Suppl 30): S19-S26. https://www.ncbi.nlm.nih.gov/pubmed/14727454.

47. Muñoz-Saá I, Cambra A, Pallares L, Espinosa G, Juan A, Pujalte F, et al. Allelic diversity and affinity variants of MICA are imbalanced in Spanish patients with Behçet's disease. Scand J Immunol 2006; 64(1): 77-82. https://doi.org/10.1111/j.1365-3083.2006.01780.x

48. Montes-Cano MA, Conde-Jaldón M, García-Lozano JR, Ortiz-Fernández L, Ortego-Centeno N, Castillo-Palma MJ, et al. HLA and non-HLA genes 
in Behçet's disease: a multicentric study in the Spanish population. Arthritis Res Ther 2013; 15(5): R145. https://doi.org/10.1186/ar4328.

49. Bettencourt A, Pereira C, Carvalho L, Carvalho C, Patto JV, Bastos M, et al. New insights of HLA class I association to Behçet's disease in Portuguese patients. Tissue Antigens 2008; 72(4): 379-382. https://doi.org/10.1111/j.1399-0039.2008.01087.x.

50. Piga M, Paladini F, Lai S, Erre G, Passiu G, Carcassi C, et al. Genetics of Behçet's disease in Sardinia: two distinct extended HLA haplotypes harbour the $B^{*} 51$ allele in the normal population and in patients. Clin Exp Rheumatol 2012; 30(3 Suppl 72): S51-S56. https://www.ncbi.nlm.nih.gov/pubmed/23021043.

51. Olivieri I, Gemignani G, Camerini E, Semeria R, Pasero G. Computed tomography of the sacroiliac joints in four patients with Behçet's syndrome - confirmation of sacroiliitis. Br J Rheumatol 1990; 29(4): 264-267. https://www.ncbi.nlm.nih.gov/pubmed/2379043.

52. Chamberlain MA. A family study of Behcet's syndrome. Ann Rheum Dis 1978; 37(5): 459-465. https://doi.org/10.1136/ard.37.5.459.

53. Lehner T, Batchelor JR, Challacombe SJ, Kennedy L. An immunogenetic basis for the tissue involvement in Behçet's syndrome. Immunology 1979; 37(4): 895-900. https://www.ncbi.nlm.nih.gov/pubmed/500134.

54. Caporn N, Higgs ER, Dieppe PA, Watt I. Arthritis in Behcet's syndrome. Br J Radiol 1983; 56(662): 87-91. https://doi.org/10.1259/0007-128556-662-87.

55. Radouane A, Oudghiri M, Chakib A, Naya A, Belhouari A, El Malki A, et al. HLA-B*27 allele associated to Behçet's disease and to anterior uveitis in Moroccan patients. Ann Biol Clin (Paris) 2011; 69(4): 419-424 https://doi.org/10.1684/abc.2011.0591.

56. Choukri F, Chakib A, Himmich H, Hüe S, Caillat-Zucman S. HLA-B*51 and $B * 15$ alleles confer predisposition to Behçet's disease in Moroccan patients. Hum Immunol 2001; 62(2): 180-185. https://www.ncbi.nlm.nih.gov/pubmed/11182229.

57. O'Duffy JD, Goldstein NP. Neurologic involvement in seven patients with Behçet's disease. Am J Med 1976; 61(2): 170-178. https://doi.org/10.1016/0002-9343(76)90166-2.

\section{Authors:}

Alireza Khabbazi - Associate Professor of Rheumatology, Connective Tissue Diseases Research Center, Tabriz University of Medical Sciences, Tabriz, Iran. https://orcid.org/0000-0002-9482-6967.

Azizeh Farshbaf-Khalili - PhD of Nutrition Sciences, Assistant Professor, Aging Research Institute, Physical Medicine and Rehabilitation Research Center, Tabriz University of Medical Sciences, Tabriz, Iran. https://orcid.org/0000-0001-5754-4613.

Leila Vahedi - MD, PhD, Assistant Professor of Medical Genetic, Liver and Gastrointestinal Diseases Research Centre, Tabriz University of Medical Sciences, Tabriz, Iran. https://orcid.org/0000-0003-0661-5885. 